This item was submitted to Loughborough's Research Repository by the author.

Items in Figshare are protected by copyright, with all rights reserved, unless otherwise indicated.

\title{
The actor's problem: performing the plays of Richard Foreman
}

PLEASE CITE THE PUBLISHED VERSION

PUBLISHER

(c) Cambridge University Press

VERSION

VoR (Version of Record)

LICENCE

CC BY-NC-ND 4.0

REPOSITORY RECORD

Swettenham, Neal. 2019. "The Actor's Problem: Performing the Plays of Richard Foreman". figshare. https://hdl.handle.net/2134/5472. 
This item was submitted to Loughborough's Institutional Repository (https://dspace.lboro.ac.uk/) by the author and is made available under the following Creative Commons Licence conditions.

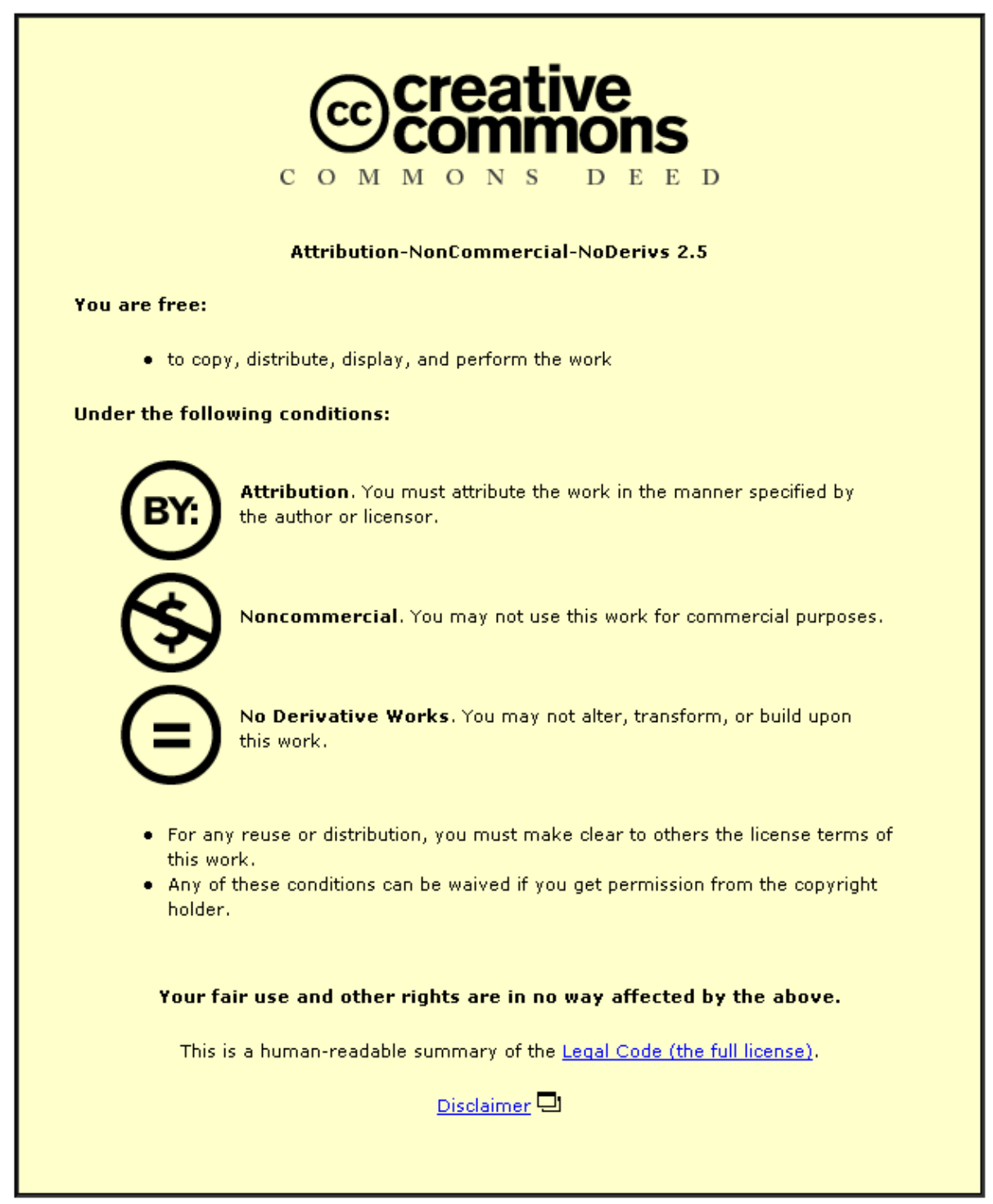

For the full text of this licence, please go to: http://creativecommons.org/licenses/by-nc-nd/2.5/ 


\title{
Neal Swettenham
}

\section{The Actor's Problem: Performing the Plays of Richard Foreman}

\begin{abstract}
The plays of the American avant-garde writer and director Richard Foreman present actors with a significant problem: their characters exist in a constant state of flux, detached from the usual narrative moorings, with the result that conventional acting methodologies do not apply. Drawing on interviews with Foreman himself, with the actors who worked with him on his New York production of King Cowboy Rufus Rules the Universe (2004), and on the rehearsal process of a student group preparing for the UK premiere of Pearls for Pigs (1993), Neal Swettenham investigates in this essay the precise challenges posed by these unusual texts. He argues that Foreman wants to provoke in his actors a sense of being permanently 'off-balance', requiring each of the performers in King Cowboy Rufus to develop their own way of navigating the play's contradictory demands. Similarly, the UK actors discovered that the unconventional dialogue, stripped of all contextual clues, must still be delivered with intention and rigour. Certain very specific European films cited by Foreman provide possible pointers to an acting style appropriate to the plays but, in the final analysis, the actor's problem remains. Neal Swettenham lectures in drama at Loughborough University. His 'Irish Rioters, Latin American Dictators, and Desperate Optimists' Play-boy' appeared in NTQ83 (August 2005).
\end{abstract}

You know, in a sense, I want less and less from the actors. I want them to internalize it but, you know, to not show too much. ... I think stories hide the truth: I don't believe in stories. ${ }^{1}$

IN SOME RESPECTS the title of this essay is a misnomer: it is unlikely that many British actors will ever have grappled with the 'problem' of how to perform the plays of Richard Foreman. During a period of almost forty years, this well-established American avantgarde writer and director has only once brought a production to Britain - Permanent Brain Damage, which played as part of the 1997 Meltdown Festival on the South Bank. This fact, in combination, perhaps, with the perceived difficulty of the work, has meant that his plays are virtually unknown in the UK. So this essay is as much an introduction to the plays as a discussion of methods: even though the one thing about Foreman's work that quickly becomes apparent is that there is no consistent methodology to be applied, no rationale that will answer all the usual questions. Nevertheless, an attempt will be made to explore the paradoxes.
We should begin by laying down one important marker: with reference to Michael Kirby's careful taxonomy of 'acting and notacting', Foreman's performers are definitely actors. ${ }^{2}$ They have dialogue to speak, 'characters' to explore, and worlds to inhabit: this is not a theatre of performers who are essentially 'being themselves', while executing a series of tasks. The problems arise because that text is so unusual, those characters are so fragmented and apparently unmotivated (at least in any Stanislavskian sense), and the worlds inhabited are so remote from any conventional theatrical landscapes.

In some respects it is reasonable to draw comparisons between Foreman's work and that of a number of other late twentiethcentury playwrights. For example, his language, like Pinter's, is superficially simple, conversational, yet insistently suggestive of ontological threats and uncertainties lurking just below the surface; like Sarah Kane - in particular in 4:48 Psychosis (1995) - his 'characters' are constantly dissolving, shifting, refusing to come into focus; like Beckett, his environments are decisively removed from 
those of our everyday reality, yet intimately connected to them. And yet, unlike either of those writers, he mixes the elements in oddly surreal combinations that render them once again distinctive and unusual, possessing a unique blend of wit and curious beauty. His plays are singular, and it is by encountering and exploring them in performance that these singularities become most engaging.

Of the more than forty plays he has written to date, two in particular - King Cowboy Rufus Rules the Universe (2004) and Pearls for Pigs (1993) - will provide a focus for this investigation. Part of the material will be drawn from interviews with Foreman himself and with the actors who worked on the original New York production of King Cowboy Rufus; further insights into the step-bystep development of the actor's role will be gleaned from the working processes of a small group of British students in rehearsal for the UK premiere of Pearls for Pigs.

\section{King Cowboy Rufus: the 'Characters'}

When it was first produced in 2004, King Cowboy Rufus was perceived by the New York critics as being unusually political for a Foreman text. ${ }^{3}$ Although no attempt was made to impersonate George W. Bush, the central character of Rufus had very clear connections with the incumbent US president. Foreman made this clear in the programme, where he noted that, while his plays do not usually 'respond to what's happening politically or socially', in this production he has attempted 'to put on stage, not George Bush himself, but a foppish English gentleman who, while seeming a figure from out of the past - yet dreams of becoming an imitation George Bush - acquiring that same power and manifesting similar limits of vision' ${ }^{4}$

To attempt any kind of narrative account of the play is to sidestep its many internal inconsistencies and misrepresent it as something other than it is. Following Gertrude Stein's famous dictum, Foreman's plays constantly 'begin again', creating a text in which the whole is always greater than the sum of its parts: the piece is simply irreducible to mere narrative description.
With that caveat in mind, though, it might be helpful to consider briefly the three main characters, as portrayed in this production. Paradoxically, the central figure, King Cowboy Rufus, is an English aristocrat who yearns to be a cowboy and takes on some of the trappings of the archetypal cowboy hero. His costume is essentially that of an eighteenth-century gentleman, yet he also sports a large cowboy hat, a holster with gun, and a Western-style neckerchief. So the character is a curious, contradictory mix of both king and cowboy. Occasionally he utters expressions such as 'Yippee ki-o!' and 'Woo hoo!' but most of his language, along with the accent, is that of the disdainful British aristocratic ruler, so that any immediate references to George Bush are concealed beneath these different layers of character.

A second male figure is identified as the Baron Herman de Voto. He is also a mix of several different and contradictory character strands. The main impression is of a cross between a gangster and some kind of state functionary. He wears a suit with multiple neckties, all swept back over his shoulders and cut off and frayed at the ends. There is a board around his neck, which is covered in medals and on which his name is written in chalk. A lace napkin, edged with pearls, perches precariously on top of a black wig, while on his feet he wears a pair of fluffy pink slippers. He identifies himself as an industrialist, the owner of a cigarette factory. He both abets and opposes Rufus's megalomaniac ambitions and frequently acts as a sardonic commentator on the unfolding action of the play.

The third and final speaking character is a young woman, Suzie Sitwell. Identified in the text as an 'English coquette', she wears a flowing chiffon dress and several conspicuous pieces of diamond jewellery, speaks with a wistful, sing-song delivery, and comes across by turns as either hesitant and rather nervous of the two men, or else unexpectedly fierce, particularly in her outspoken acts of resistance to King Cowboy Rufus.

Although there are other performers on the stage - an ensemble of silent characters, in fact, who are very important in terms of 
the visual imagery of the piece, and who constantly fill the space with props, movement, and gesture - I shall nevertheless concentrate on these three speaking roles, since it is the actors' engagement with the spoken dialogue with which this essay is most concerned.

\section{King Cowboy Rufus: the 'Narrative'}

The first thing one notices about the text is its constant use of non sequiturs and broken trains of thought. Almost as soon as a phrase is uttered, the direction of the conversation changes again, moving us rapidly from one disconnected idea to another. The opening lines set the tone for all that is to follow:

BARON: You can't know the answer to this riddle. Come to think of it ...

SUzIE: My name is Suzie. Remember that name. BARON: I don't even know how to properly formulate this riddle. HELP ME! HELP ME! SUZIE: I'm ready.

BARON: You know what? The truth is always best. I'm so sorry, my elegant little cigarette girl coquette - but due to economic instability, I suppose - I, Baron Herman de Voto, I am forced to close my cigarette factory. You can't see it, of course - because like everybody else, I have my secrets. But you can still smell it. It stinks. It STINKS!

SUZIE: Yes. It stinks. But you owe me my wages,

Mr Baron bastard whatever you call yourself. BARON: OK. Maybe you'll have to sing for your supper. $^{5}$

Any hope that the ensuing dialogue might clarify the situation or the precise relationships between the characters is misplaced. Foreman has famously described his plays as being rather like the experience of watching the first ten minutes or so of a film - the period of time during which an audience is groping to make sense of the fragmented action and dialogue, and when characters speak cryptically of people and situations that are, as yet, unknown to the viewer. ${ }^{6}$ The main difference, however, is that, whereas with the film the mystery is gradually unravelled, 'Foreman tries to stretch the charged atmosphere of these ten minutes over an entire evening ${ }^{\prime}{ }^{7}$ You have the constant sense that if you keep watching for just a few more

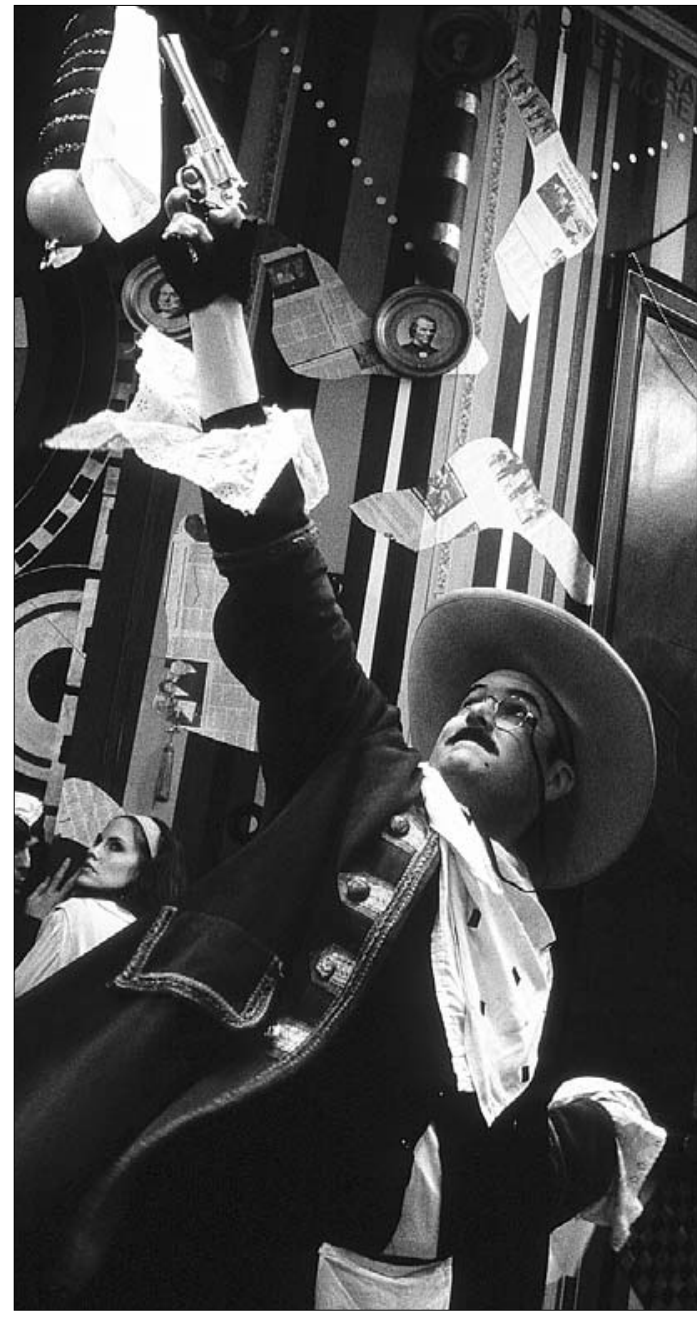

Jay Smith as King Cowboy Rufus, the English aristocrat who yearns to be a cowboy (photo: Paula Court).

minutes, everything will become clear: but it never does.

And it is this, of course, that provides the central acting problem. In conventional character-based acting, one is encouraged to look for the 'through-line' of character, to piece together the clues that will help one to understand a character's 'super-objective', and thus to determine the motivation for individual lines and actions. But with Foreman's texts such a quest is probably fruitless and certainly problematic. As Marc Robinson points out, Foreman's characters

reinvent themselves with every sentence, acquiring new virtues and vices, discarding their original beliefs before they (or we) have examined them 
adequately. They sever relationships with one another and welcome distraction. Sometimes, they even change their names. The entire play seems to shed a skin - and then another skin, and still one more. The process makes most audiences dizzy. ${ }^{8}$

Along with making audiences dizzy, this also makes life very difficult for the actors. Juliana Francis, the actress playing Suzie, who has worked with Foreman on three previous occasions, describes the experience as:

Totally disorientating. I've always done experimental work, but I come from a Meisner background, which is very Method, and with other pieces that I've done that have been non-linear or include a lot of dance, video, different kinds of disruptions, it's always been easier to still get out my naturalistic toolbox and create some kind of arc, or so-called journey, or something that made sense to me in a causal way. But I find that Richard's work is the most resistant to more traditional acting techniques. ${ }^{9}$

That resistance generates a variety of acting solutions. Talking with the three performers, it soon becomes clear that each of them has developed their own personal method for achieving the desired results. And, indeed, it is specific results that Foreman is interested in, rather than the precise means used to achieve those results: 'Unlike most other directors working in the theatre, I prefer not to involve myself with the actor's process. ${ }^{\prime 10}$ And again: 'I tell them that I'm counting on them to build their own internal justification for what they're doing. I don't care to know about it. ${ }^{\prime 11}$

\section{King Cowboy Rufus: the Actors' Responses}

Having said that, it is also clear, both from Foreman's own comments about his work as a director and from the way the actors themselves speak about the rehearsal process, that he constantly nudges and steers that process in any number of different ways in order to achieve what he is looking for:

I have no programme. Even though I'm pretty much aiming for the same quality of a certain sort from the performers, there's no rule on how to get it from every performer, because every performer is different. ${ }^{12}$
The specific 'quality' that Foreman seems to be looking for is that of being constantly 'off-balance', both physically and mentally. Juliana Francis describes this as a 'kind of oscillation that he wants you to arrive at, so you never really are in a kind of state that makes you feel secure. It's always this unsettled feeling, instead of landing things, and nailing things, and confidently fulfilling something. ${ }^{13}$ For her, the initial route towards reaching this state was to think in terms of using a very restricted range of responses:

I remember the first two shows I had to just keep thinking in terms of things like organic brain injury. I just couldn't figure out how to create the behaviour in a way that I could understand and that fulfilled what he was asking for us to do. I would give myself impediments, like I would pretend that I had certain kinds of like temporal lobe injuries to justify the kind of behaviour that he was pushing us towards, because in naturalistic terms I was really at a loss to justify for myself in a way that would keep the performance where it should be. ${ }^{14}$

Now, having had more experience of working on these texts, she describes the process more positively in terms of observation and release:

And it was, oh, you know, I don't have to do anything: all I have to do is, like, look at these weird objects that keep entering on this strange landscape. And so I just decided that was all I was going to do. . . . In this work I think it tends to be ... you just keep letting it go. So you see something, you respond, you let it go. You see something, you respond, you let it go. ${ }^{15}$

I feel like I've been learning more about how my brain works, 'cause I watch things and then I feel my brain drift - it's sort of like a drunken monkey idea, like, er . . you talk about meditation. And it's so interesting to just not even judge that drift, but just correct it, correct it, correct it, as you move through the play. And that kind of allows you to find a rhythm that you couldn't impose on things, or anticipate, and an acceptance of things. ${ }^{16}$

But navigating a course through such a narrativeless drama is not easy. For Jay Smith, another experienced Foreman actor, who in this production plays the character of King Cowboy Rufus, the answer is to see the performance as a series of 'tasks' ${ }^{17}$ He suggests that the character 


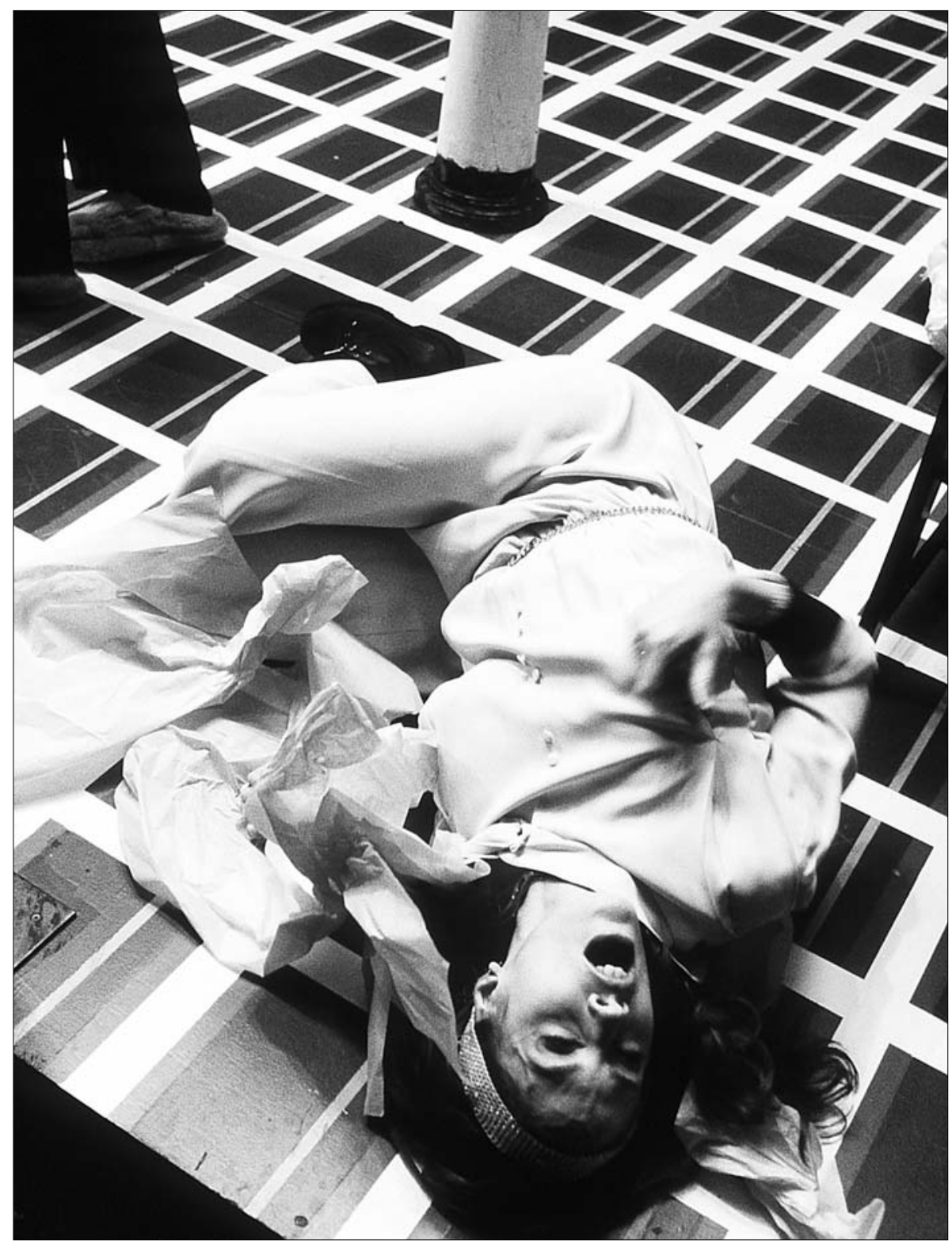

Juliana Francis as Suzie Sitwell in King Cowboy Rufus (photo: Paula Court).

gets guilt because there are a series of tasks that have to be accomplished and that - so, you're basically working from the back end, it's very mechanical. . . . I need to create a structure that is repeatable, and then I need to repeat it many, many times. And then, that actually creates an arc of its own. With this work, I don't do a lot of psychological work at all. At all. ${ }^{18}$

This more 'mechanical' approach comes directly out of the way that Foreman rehearses his actors, asking them to execute specific physical movements as they say any given line, without necessarily giving them any motivation for those actions (and frequently changing and revising those instructions), and it is a method that enables Jay to create his own, different kind of 'arc' through the performance. But such a way of working relies upon that kind of precise physical choreography being made available: it works well when Foreman himself is at the helm, but would not necessarily be applicable if a different director were in charge.

Nor was it the solution for the actor playing the Baron Herman de Voto in King Cowboy Rufus, T. Ryder Smith (Tom), for whom 
this is the first experience of working on a Foreman text:

It's not at all a linear process; it's not at all a cumulative process, as in adding character on, or adding depth to a character. But I had no idea what to expect in terms of the actual work. ${ }^{19}$

Having seen a number of previous Foreman shows, Tom was familiar with the unusual, presentational style of performance, but the fact that he did not know what to expect from the rehearsal process made him acutely aware of the new and difficult demands that the text was making on him. His detailed description of the problems he faced, and of one very significant solution that he found, sheds a fascinating light on the workings of these plays and is therefore quoted at length:

Richard was frequently telling me that I was acting too much, throughout the rehearsal process, which I found a wonderful note; just a salutary note each time, just a reminder to not act, to get rid of the actor's tricks. So I would attempt to play a kind of through-line, which I was told was wrong. So then I attempted to play simply perverse non sequiturs ... just completely juxtapose irreconcilable ideas on every line. And he told me I was thinking too much. I realized that if anything showed in the eye that looked motivated, if there was any kind of psychological cause to the line reading, or intention to the line reading, that's what he didn't want.

So I had to find a way to abstract it, and yet still be playing needs and intentions on the line. I found that if you play metaphor, it tends to work. If you play the metaphor of what you're doing, if you recognize ... . For instance, I found - do you know the Bohemian Grove retreat? It's in Northern California; it's this sort of summer camp for world leaders. The George Bushes of the world, the Dick Cheneys of the world, have this compound that is their summer retreat and they go there to not only decide on the future of the so-called Free World but also to have these strange picnics, and vaudevilles, and joke nights. And apparently there's always a drag performance. The idea of world leaders with coconut shells and hula skirts, you know ... that's what I'm playing.

It's a political drama, and I realized the day I played that, I felt it was right. I am William Paley, who used to run CBS TV, at Bohemian Grove, performing a sketch, and the audience are the Shah of Iran, the Prince of Monaco, etc. I mean, world leaders from the fifties and sixties. Basically, that's my metaphor. As long as I'm in that metaphor, that somehow gets me on track for the tone. And then any variation off the tone still reverts ... it has the resonance of the tone. That's the tone I'm going for: this bizarre world-leader performance at a drunken picnic and the like in $1960 .{ }^{20}$

Tom articulates clearly here the central difficulty of these plays: these lines are written to be 'played'; it is not enough 'simply' to say them (as tended to be the case in many of Foreman's early productions). 'I had to find a way to abstract it, and yet still be playing needs and intentions on the line.'

\section{Pearls for Pigs: Lines on a Page}

It was a similar dilemma that faced a group of UK students later that same year as they started work on a production of Foreman's 1993 play, Pearls for Pigs: how to play needs and intentions on the line, when so little in the play 'adds up'. Once again, the title gives some indication of the central idea of the work - in this case, the difficult relationship between artist and audience - though, again, any narrative account of the play tends to multiply the complexities of the text rather than to contain them. ${ }^{21}$

It was a dilemma that was further compounded by a determination to take seriously the author's suggestions for producing any of his plays:

Erase all the stage directions, even the assignment of characters, and use the naked text to then reimagine a new scenario - whatever the pure dialogue suggests to the director. ${ }^{22}$

So the company began their rehearsals with a stripped-down script that was 'pure dialogue' and gave virtually no indications of setting, speaker, or any kind of stage action.

It was an unusual and baffling experience for these young actors to be faced with apparently unmotivated speech that, while it certainly had all the appearance of being strongly character-driven, could not easily be assigned to any one character in particular. In fact, they were completely unnerved by the lack of information in the script and the absence of any kind of logic. The atmosphere in those early rehearsals felt a little as though the cast would have preferred to have been starting work on a production of Twelfth Night, where 
the textual clues are there waiting to be found and everything that's necessary to understanding has been provided in advance by the author. As one student actor commented: 'We thought it would be impossible when we first saw the script. How on earth do we work from just lines on a page?' ${ }^{23}$

Those first 'lines on a page', stripped of all character and scenographic information, plunged the performers straight in, suggesting a situation, but not a context:

- I hate the actors who appear in this play.

- Oh no, no! I rather like the actors who appear in this play, even you, Maestro. What I hate is the play.

- Oh no, no, no, I like the play very much, but I hate the actors.

- I have an idea. Let's reverse roles.

- Ah, what an unsettling idea.

— I'm bleeding. I'm bleeding.

- Oh, my God! ${ }^{24}$

How does one begin to interpret this sequence of constant interruptions? Foreman himself talks in a number of places about the crucial importance of following the 'impulse' as the guiding principle within his work:

IMPULSE, of course, need not just mean hitting someone on the nose - it may also mean reaching for an unsettling idea, or letting words surface from the unconscious. The point is: ART IS THE PLACE TO ALLOW THAT WHICH CANNOT REALLY HAPPEN IN LIFE, TO HAPPEN IN ITS FULL, RICH, RADIANT, ABUNDANT GLORY.

But-HERE'S THE MOST IMPORTANT PART - in my plays, the manifestations of impulse are not just narrated, but rather THE SAME IMPULSE THAT PUSHES THE CHARACTER INTO 'ACTING OUT' ALSO TWISTS AND CONTROLS THE ARTISTIC STRUCTURE, so that the form and sequencing of the play itself reflects that impulsive, usually suppressed, energy of the human mental/emotional apparatus. $^{25}$

The initial read-through, therefore, was a useful first opportunity to allow the company's own impulses to come to the surface. As the students read the dialogue around the circle, they all had access to an additional copy of the script, pasted on to much larger sheets of paper. Whenever any of them had an 'impulse', connecting a sound, image, gesture, or fragment of action to the words that they, or anyone else, were saying, they quickly jotted those ideas down on the large sheets in front of them. That script quickly became a communal ideas-bank for the production.

\section{Pearls for Pigs: Inhabiting the Dialogue}

However, helpful as the ideas-bank was as a source of creative inspiration, it did not begin to address the central problem of how to inhabit these apparently random snatches of dialogue. Indeed, randomness was the students' main strategy in their first attempts to put the text on its feet. In early rehearsals and workshops, the co-directors adopted an approach of disconnecting the speeches from all moorings in logical sense, allowing their performers to generate movements, gestures, intonations, and intentions at will.

The results were mixed, to say the least. An early run of four separate sections of the play made the text appear dull and uninteresting, draining the words of life and vitality. The actors were floundering: they committed themselves to making strange noises, artificial and energetic gestures, but it was all curiously empty and unengaging. One of the students later expressed the sense of frustration that the absolute and unrestrained freedom of having dialogue with no context had generated in them:

I think one of the things about having such an open script with so few limitations is, as an actor, the first thing you're going to do is put limitations on yourself in certain positions, just so you have some boundaries to work from. 'Cause if it's, like, 'Do whatever,' the first thing you think is, 'What do I do?'

A key breakthrough came at a point in the rehearsals when the actors stopped trying to 'get it right' and began to trust themselves to feel their own way into the multiplicity of meanings that lie buried in the text. Just like the American actors, who had been directed towards it by Foreman, the students found intuitively that some kind of solution to the problem lay in that oscillation between sense 
and non-sense, and in tracking the constant flux of contradictory intentions and desires. In some respects, it quickly became a more natural way to act than seeking for a Stanislavskian through-line:

I think it's easier to do it without thinking of an actual character the whole way through. With this text everything I say, I'm in between liking the theatrical world and disliking it at the same time. I contradict myself a thousand times a day. It's more true to life than an ordinary text.

What the actors realized was that, despite the seeming randomness of the script, at any given moment they still needed to know for themselves what they were saying and why they were saying it. It was not enough just to speak the lines out and hope that the surreal illogic would somehow make the text seem interesting. Nor was the solution to act 'louder', yet without any clear sense of purpose. As T. Ryder Smith had found, when rehearsing the role of the Baron, with these texts it is not a case of being purely arbitrary in one's choices: it is, instead, necessary to 'play the metaphor' that will make 'sense' of the lack of sense.

There also need to be strong connections between the characters. In many of the early rehearsals, the students spoke their lines randomly, into the empty air. Yet as they learned to direct the lines to each other, with detailed and specific thoughts behind them, the texture of the performances began to thicken. The students had discovered that they must find their own ways to play specific intentions and choices, though without 'thinking too much'. 'Initially, I just read the lines; they didn't mean anything. Now I know what I'm talking about, even if you don't.'

Above all, the actors began to realize the full implications of the requirement for the performance to create the illusory sense that explanation is possible - though always just out of reach. The audience must be made to feel that if they watch for long enough - just a few more minutes, perhaps - they will ultimately make sense of the mystery. The play must constantly pose problems and provoke questions. Why are the characters behaving in this way? What are the precise relationships between them? What is the key to understanding their puzzling behaviour?

Although the key breakthrough occurred just days before the production opened, for a number of the performers it was the presence of an audience that finally established this key principle of the text: 'I've never seen an audience react like this before: it helped me understand it.' And: 'I didn't "get" my main speech until I had an audience. That speech is about playing off the audience.'

\section{Read Everything You Can, Then Ignore It}

Intriguingly, Foreman's own observations on how to act his texts tended to confuse the student actors as much as to assist them. They found that as long as they were 'trying to be Foreman', they became anxious and frustrated. To some extent this can be put down to inexperience. Yet it could also be argued that this is actually a desirable outcome, for just as Foreman wants his audiences to be permanently 'off-balance', so he also insists that his performers should be constantly unsettled and unrelaxed onstage:

The basic Stanislavsky method, as it has been taught in America, trains an actor to find a way to be relaxed during performance, even within a highly emotional scene. Most twentieth-century art, however, is not about being relaxed. Ours is an era of stress, and serious art reflects that stress, even if it wants to establish an alternative. The plays I write reflect that stress, and I think the performers should as well. ${ }^{26}$

Consequently, Foreman's published instructions to actors include suggestions such as:

Be hostile toward the audience. . . . Always be ready to defend yourself. ... Assume that the stage is full of landmines. . . . Assume that the stage is covered with broken glass. ... 27

This all-pervasive sense of hostility, or of guarded awareness, is certainly one of the most striking features of Foreman's own productions. His actors are undoubtedly 'present' throughout: their sense of focus on the performance space itself, on the objects and other performers within that space, and on the observing audience, is typically intense 


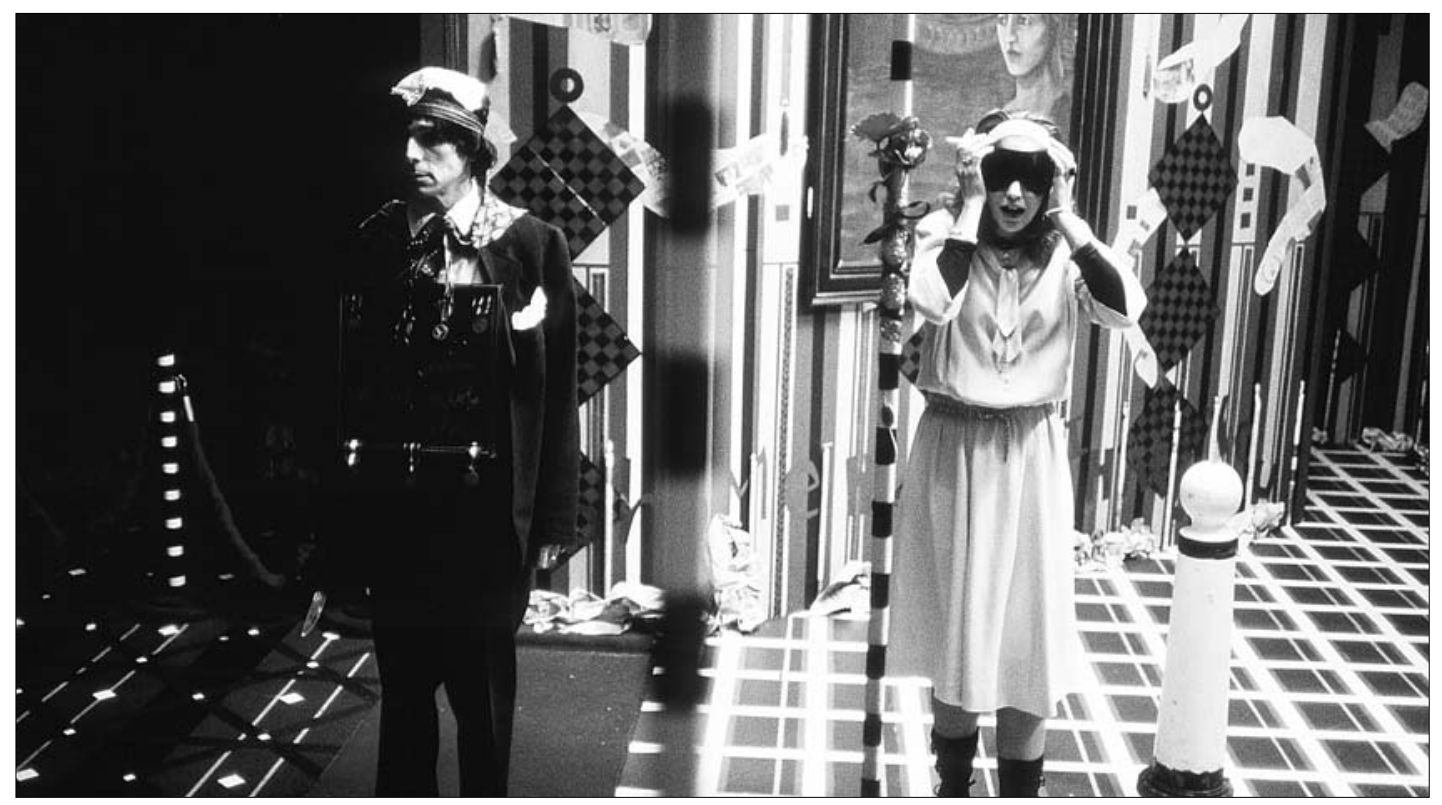

There is a strong sense of threat and hostility on Foreman's stage. T. Ryder Smith and Juliana Francis in King Cowboy Rufus (photo: Paula Court).

and sustained. Movement is never wholly casual or naturalistic. No one merely 'strolls' in a Foreman play: they stalk, attack, confront, pounce, and encounter.

A comment from Juliana Francis sheds further interesting light here. She notes that Foreman recommends his actors to view certain European films as a way of understanding the style he is aiming for. In particular, she mentions Robert Bresson's Mouchette (1967). The film is an uncompromising representation of French village life in a situation that is both spiritually and emotionally starved. In particular, it focuses on the experiences of a fourteen year-old girl, Mouchette, who is abused in various different ways by a string of adults, including her father, her schoolteacher, and a local poacher.

The film's narrative structure is essentially conventional, although the motivations and inner thoughts of the characters are more concealed than is often the case in film. Its most immediately striking feature, however, in terms of acting style, is the focused intensity that all of the performers bring to the work. There is a particular form of cruelty at work here that is not, perhaps, as apparent in Foreman's theatre, but what is recognizable from both is the strong sense of threat and hostility: these characters act and react to each other with well-founded suspicion. They creep up on each other, threaten and interrogate each other, always searching out the other's motives while hiding their own. Foreman adds a large dose of comic absurdity to this mix which strongly differentiates the two styles, but the comparison may provide interpreters of Foreman's theatre with a valuable visual frame of reference.

A second film, cited on more than one occasion by Foreman, is Roberto Rossellini's Voyage to Italy (1953), in which Ingrid Bergman and George Sanders play a couple whose genteel marriage is gradually disintegrating under the pressure of unfamiliar cultural surroundings. The piece was coolly received by critics when it was first released due to its rambling, non-linear narrative and roughedged editing style; but it is these very elements that Foreman particularly values, together with the low-key tone of the acting.

In fact, to describe the central performances in these terms could be misleading: to our eyes, the acting looks mannered, with a rather stilted, melodramatic quality about it. However, the way that simple phrases, such as 'Have a good time?' or 'I don't even want to talk about it' are invested with a much 
deeper significance is, of course, a recognizable feature of Foreman's own plays, in which the language of everyday transactions becomes similarly laden with additional metaphysical weight and substance. The film accentuates the hostilities and cruelties lying just beneath the surface of the most casual encounters, and this leads us back once again to the sense of intense concentration and focus that the plays themselves demand.

\section{The Excitement of Not Understanding}

These films can offer us interesting external clues as to the style that Foreman himself is aiming at when he directs his own productions; but inevitably, actors and directors approaching these texts still have to find their own solutions, without relying slavishly on the author's instructions. Foreman's comments about productions of his plays directed by others betray a certain ambivalence: while he actively encourages experimentation and radical re-imaginings of the texts, he rarely seems pleased with the results.

I think you've got to sense that there's some rigour at work; that it's not just 'anything goes' with something you don't understand. But being in a state of not understanding when you think something rigorous is going on is the most exciting place to be. If you've understood something, the minute you understand it, you've sort of killed it ... and it's no longer interesting. ${ }^{28}$

What this particular group of actors finally discovered on their own account was that Foreman's lines cannot be delivered 'randomly', just because they don't happen to make sense at first, second, or indeed, any subsequent reading - they have to be intentional. And the intentions cannot be gleaned, as in more conventional scripts, from any of the usual channels, such as ideas about locating a unified character, super-objectives, or any form of through-line. But, predictably, this personal ownership of the text became far more important for these actors than any of the individual stylistic tools suggested by Foreman. As one of the cast put it, when asked for the single most important piece of advice he would give to an actor approach- ing the plays: 'Read everything you can about Foreman - and then ignore it!'

\section{Notes and References}

1. Richard Foreman, Trust Me: Working with Richard Foreman (DVD, Loughborough University, 2006).

2. Michael Kirby, 'On Acting and Not-Acting', in Acting (Re)Considered, ed. Phillip B. Zarrilli (London; New York: Routledge, 2002). Certainly this is the case in Foreman's plays from the mid 1980s onwards: in many of the earlier productions, the acting style was noticeably less formalized.

3. Ben Brantley's review of the production for The New York Times, 16 January 2004, was entitled, 'Richard Foreman's Foray into Politics'.

4. Richard Foreman, programme notes for King Cowboy Rufus Rules the Universe, Ontological-Hysteric Theater, New York, 8 January-18 April 2004.

5. Text taken from an unpublished copy of the script, 'King Cowboy Rufus', due for publication in a collection entitled Bad Boy Nietzsche! and Other Plays by Theatre Communications Group, October 2007.

6. Marc Robinson writes about this in his introduction to Richard Foreman, My Head Was a Sledgehammer: Six Plays (Woodstock; New York: Overlook Press, 1995), p. ii.

7. Ibid.

8. Ibid., p. i.

9. Unpublished interview with Juliana Francis and T. Ryder Smith, 19 February 2004.

10. Richard Foreman, Unbalancing Acts: Foundations for a Theater (New York: Theatre Communications Group, 1992), p. 44

11. Unpublished interview with Richard Foreman, 18 February 2004.

12. Ibid.

13. Unpublished interview with Juliana Francis and T. Ryder Smith, 20 February 2004.

14. Interview, 19 February 2004.

15. Ibid.

16. Interview, 20 February 2004

17. Not, though, in the sense of task-based performance. Cf. Philip Auslander, 'Task and Vision: Willem Dafoe in LSD', in Acting (Re)Considered, op. cit.

18. Unpublished interview with Jay Smith, 19 February 2004 .

19. Interview, 19 February 2004.

20. Ibid.

21. Michael Patterson has a good stab at it, though, in The Oxford Dictionary of Plays (Oxford: Oxford University Press, 2005), p. 312.

22. Richard Foreman, Paradise Hotel and Other Plays (Woodstock; New York: Overlook Press, 2001), p. 13.

23. Taken from an unpublished interview with the student actors recorded on the last night of their run, 4 June 2004. All subsequent comments by the company are from this same group discussion.

24. The opening lines of dialogue from 'Pearls for Pigs' in Richard Foreman, Paradise Hotel and Other Plays, p. 193. All character and staging information has been removed from the published text.

25. Ibid., p. 8, capitals as in original.

26. Richard Foreman, Unbalancing Acts, p. 41.

27. Ibid., p. 41-2.

28. Richard Foreman, Trust Me, 2006. 